\title{
Pentazocine Hydrochloride
}

National Cancer Institute

\section{Source}

National Cancer Institute. Pentazocine Hydrochloride. NCI Thesaurus. Code C47661.

The hydrochloride salt form of pentazocine, a benzomorphan narcotic agonist-

antagonist. Pentazocine hydrochloride binds to and activates kappa- and sigma-opioid

receptors, resulting in sedation and analgesia. In addition, this agent antagonizes the mu-

receptor. Pentazocine hydrochloride partially reverses opiate-induced cardiovascular, respiratory, and behavioral depression. 